\title{
ANALYSIS OF IMAGERY IN FIVE SELECTED POEMS BY MAYA ANGELOU
}

\author{
Siti Angreini Arbi \\ English Literature Department, Faculty of Cultural Science, \\ Universitas Muhammadiyah Gorontalo \\ angreiniarbi@gmail.com
}

\begin{abstract}
This research is qualitative descriptive research that analyzes five selected poem of Maya Angelou "I Know Why the Caged Bird Sing, Still I Rise, Phenomenal Woman, When I Think about My Self and the last is Alone". The researcher used qualitative method and structural approach to know what kinds of imagery that used in five selected poem by Maya Angelou "I Know Why the Caged Bird Sing, Still I Rise, Phenomenal Woman, When I Think about My Self and the last is Alone". Than, the data were collected from five poems that selected by Maya Angelou. In the process analyzed, the researcher read the poem "I Know Why The Caged Bird Sing, Still I Rise, Phenomenal Woman, When I Think About My Self and the last is Alone" and using five steps based on the technique of analyzing the data by using structural approach to find what kinds of imagery that used in poem "I Know Why the Caged Bird Sing, Still I Rise, Phenomenal Woman, When I Think About My Self and the last is Alone" by Maya Angelou. Then based on the result of this analyzed, the researcher found there are four types of imagery that Maya Angelou used in his poem "I Know Why the Caged Bird Sing, Still I Rise, Phenomenal Woman, When I Think About My Self and the last is Alone" Those are visual imagery, auditory imagery, tactile imagery, gustatory imagery and last is kinesthetic imagery, but the kinds of imagery that very dominant used is auditory imagery.
\end{abstract}

Keywords: Poetry, Imagery, Method and Approach

\section{INTRODUCTION}

One of study about literature is poetry. Poetry is part of the science literature. Literature in the language Sanskrit means writing. Poetry including one a genre of literature that contains expression of feelings of the poet, containing rhyme and rhythm, and disclosed in options Careful and precise words (Departemen pendidikan dan Kebudayaan, 1997: 794). Characteristics of poetry can be seen from the language used and the form of the poem. Its language contains rhyme, rhythm, and figuratively. A form of poetry can be seen of shape form the temple, organized layout, and not be concerned with spelling.

The definition of the poem itself is still too difficult to be defined. Mostly experts have made the definition poetry from various viewpoints their own. 
Literary genres will divide into two parts: imaginative literature and literary non imaginative. Imaginative literature itself has the characteristics of contents that is imaginary, using language connotative and meet the conditions before aesthetic requirements.

Samuel (Pradopo, 2007: 6) suggests that poetry is the most beautiful words in the most beautiful arrangement. The poet chooses that poem is the right one and is arranged in a complete, published, symmetrical meaning between the nonothers and the very perfect. The definition of the poem above include wide enough for interpreting the meaning of the poem as a result of networking experience who can or experienced by someone and arranged systematically as meaning one and the other. From the definition above also mean that the poem is a work of art that is closely related to the language and spirit. Composed by words either as a result of the outpouring of the media that is both imaginative writing by the author to highlight aspects of her life. Based on the author argues that poetry is essentially an outpouring of feelings of its creator so the existence of a poem is inseparable from the existence of thoughts, feelings, and the environment of the author. If someone dive into a poem meaning he is trying to find who and how the existence of the creator. Therefore, to recite poetry does not express the meaning other than in accordance with the taste of the poet.

Poetry has structures that is intrinsic images, because in this analysis will discuss the images. Images are imaginations in mind and language that describe them Alternbernd (Pradopo, 2007: 79). Average minds each image is called the imagery. So every poetry has an imagery, Imagery Could be interpreted as a depiction of the experience associated with an object, event, situation that the poet experienced using typical words in order to provide a more real picture, good things that are psychological, material, and metaphoric. There are several types of imagery: Visual imagery or (Sight), Auditory Imagery or (Sound), Tactile Imagery or (Touch), Olfactory Imagery (Smell), and the last is Gustatory Imagery or (Taste).

Seeing the importance of images in a poem, then absolutely someone who wants to interpret a poem must understand these elements. Understanding of these 
elements can be done with structural analysis or what is called structural analysis. Structural Analysis of poetry is an analysis into its elements and their function in the structure of poetry and the elaboration that each element has a meaning of the work in relation to other elements, even based on its place in the structure (Pradopo, 1995: 120).

Based on some explain about poetry and the intrinsic above, the researcher interested to analyze the imagery in some of Maya Angelou's poems. So, the researcher conduct research entitled Analysis of Imagery in five selected poems by Maya Angelou.

\section{RESEARCH METHOD}

In this research, the researcher used qualitative method to analyze five poems by Maya Angelou the poems are follow I know why the caged bird sing, Still I rise, Phenomenal woman, When I think about me, and the last is Alone. According to Denzin and Lincoln (1994), "qualitative research focuses on interpretation of phenomena in their natural settings to make sense in terms of the meanings people bring to these settings. Qualitative research involves collecting information about personal experiences, introspection, life story, interviews, observations, historical, interactions and visual text which are significant moments and meaningful in peoples' lives". So by using qualitative method the researcher want to know more about the meaning and the imagery that using in Maya Angelou's selected poems, and the researcher used structural approach or more specific is objective approach. Objective approach is paying attention full on an autonomous literary works the intrinsic coherence. In order to study literature, either physical and poetry, there are some models can approach in apply; and application of the model in accordance with the concepts and procedures each work, Abrams (1979), for example, has divided the model The approach into four large group, and four groups it can be viewed as a model who has been covering the whole situation and orientation of the literature.

The approach discussed objectively most end with a consideration that This approach is precisely the approach is important as well The most closely 
linked with modern literary theory, particular theories using the basic concept of the structure.

Described by Abrams (1979: 3-29) that models that highlight study of the role of the author as the creator of a literary work called expressive; which is more focused the role reader as a greeter and appreciation literature called pragmatic; more oriented aspects referential in relation to the real world is called mimetic; while paying attention full on an autonomous literary works the intrinsic coherence called more objective approach. So, to identify the intrinsic structures in Maya Angelou selected poems the researcher will use structural approach.

In this research, there are two sources of the data that the researcher used primary data and secondary data. The primary data in this research is some of Maya Angelou selected poems those are I know why the caged bird sing, Still I rise, Phenomenal woman, When I think about myself, and the last is Alone. Because the poem is the directly provide data. And the secondary data in this research is through another data from other person or trough document from some books, because the secondary data is the data sources will use just to more complete the primary data.

Data collection techniques are the most strategic step in research, because the main purpose of research is to get data. Sugiyono (2013: 224). In process of collecting the data the researcher doing some step, first is the researcher searching some of the famous poems by Maya Angelou, second is the researcher selected some poems that the researcher interesting to analyze and the last is the research select five poems of Maya Angelou. The poems is I know why the caged bird sing, Still I rise, Phenomenal woman, When I think about me, and the last is Alone.

According to Bodgan (Sugiyono, 2012, p. 88) "analyzing data is the process of systematically searching and arranging the interview transcripts, field's notes, and other materials that you accumulate to increase your own understanding of them and to enable you to present what you have discovered to others". So, to analyze the data the researcher will use five step, identification 
data, classification data, interpreting data, describing data, and the last is conclusion.

The first step is Identification, the researcher will identification the sources to find out the problem that will analyze. Second step is classification, the researcher will classify the data collected from the primary and secondary data above to be analyze, the third step is interpreting, in this step the researcher will interpret the poem to find the meaning deeply or understanding more about the poem. Describing is the fourth step, the researcher will describing the meaning of the poem and find out the imagery that used in the poem. And the last step is conclusion, after doing the fourth step above the researcher will conclude the result of the data collected to answer the research question in this research.

\section{RESEARCH FINDING AND DISCUSSION}

This chapter presented the research finding and discussion based on the data that the researcher got from the object of the research. The content of this part consist of finding and discussion based on the analysis.

This is some of the data that the researcher found based on the analyze of imagery in five of Maya Angelo's poems those are is I know why the caged bird sing, Still I rise, Phenomenal woman, When I think about myself and the last is Alone.

\section{Visual Imagery}

Visual imagery appeals to the sense of sight by describing something the speaker of the poem sees.

For the first poem is I know why the caged bird sing. The speaker in this poem is Maya Angelou, she resemble her as a caged bird that cannot do like a free bird do. She made this poem based on the story of her life about her childhood as a black girl in the deep South that different with many and make her depressed. In first stanza:

Line 1 - A free bird leaps on the back 
In this line the speaker tells about a free bird leaps on the back wind that means she can do anything she wants. The word of bird is included in visual imagery, because bird is an animal so the reader can see the bird in their imagination.

Line 4 - in the orange sun rays and dares to claim the sky.

The speaker describes how happy the free bird that can see how beauty of the orange sun rays and dares to claim the sky

In second stanza:

Line 5 - But a bird that stalks down his narrow cage

The speaker tells a caged bird that stalks down his narrow cage, that means she compare between a free bird that can fly like she wants but a caged bird that stalks down his narrow cage just only can see through his bars of rage.

Line 7 - his wings are clipped and his feet are tied In this line the speaker describe how tortured the caged bird because his wings are clipped and his feet are tied so she cannot fly and go to the other place to do whatever she wants. So she just stays on her caged narrow and sing.

In forth stanza:

Line 15 - and the fat worms waiting on a dawn bright lawn In this line the speaker tells how happy the free bird can search her food by herself in dawn bright lawn.

In fifth stanza:

Line 18 - his shadow shouts on a nightmare scream

The speaker tells how tortured the caged bird, even his shadow shouts on a nightmare screams in this line.

Based on Pradopo, (1990: 81) visual imagery appeals to the sense of sight by describing something the speaker of the poem sees. Poets will use other figurative language, such as metaphor, simile or personification to describe these images. So the words of bird, orange sun rays, narrow cage, wings are clipped, his feet, fat worms on a dawn bright lawn and his shadow in this poem is include of visual imagery because the speaker of the poem describes what objects she sees or makes them seem like something else. 
Second poem is Still I Rise. Still I Rise is a powerful, empowering poem all about the struggle to overcome prejudice and injustice. This stirring poem is packed full of figurative language and when read through comes over as a sort of secular hymn to the oppressed and abused. The message is loud and clear - no matter the cruelty, regardless of method and circumstance, the victim will rise up, the slave will overcome adversity. It is one of Maya Angelou's most popular poems and this poem has nine stanzas but the visual imagery sense used only in five stanzas.

In first stanza:

Line 3 - You may tread me in the very dirt The speaker in this poem tell however they abused or tread her in the very dirt she accepted. The word of very dirt that included of visual imagery.

Line 4 - But still, like dust, I'll rise.

The speaker in this poem tell no matter that happens to her although like dust she will rise. The word of $d u s t$ that included of visual imagery.

In Third stanza:

Line 9 - Just like moons and like suns,

The speaker in this poem tell if like moons and like suns although with the certainty of tide, like hopes springing high she will still rise. The word of moon and suns included of visual imagery.

In seventh stanza:

Line 25 - Does my sexiness upset you?

The speaker in this poem is tell what's make them upset with her so it make them want to kill her. Does my sexiness upset you?

The word of sexiness included of visual imagery.

In eighth stanza:

Line 33 - I'm a black ocean, leaping and wide,

The speaker in this poem tell if whatever they do to her she will rise she like a black ocean, leaping and wide, welling and swelling she bear in the tide. The word of Black Ocean included of visual imagery.

Next is the last stanza: 
Line 35 - Leaving behind nights of terror and fear

Line 37 - Into a daybreak that's wondrously clear

The speaker in this poem tells although she leaving behind nights of terror and fear she will rise into a daybreak that's wondrously clear she rise. The word of night and daybreak included of visual imagery.

Based on Pradopo, (1990: 81) visual imagery appeals to the sense of sight by describing something the speaker of the poem sees. Poets will use other figurative language, such as metaphor, simile or personification to describe these images. So the words of very dirt, like dust, like moons, like suns, my sexiness, black ocean, nights and a daybreak is include of visual imagery because the speaker of the poem describes what objects she sees or makes them seem like something else.

Third poem is Phenomenal Woman. Phenomenal Woman is a lyrical poem that sends out an important message to the world of convention and stereotype: empowerment comes from being confident in your own female skin, no matter if you are not seen as cute or fashionable by the masses. Phenomenal woman has four stanzas

In first stanza:

Line 1 - Pretty women wonder where my secret lies.

Line 2 - I'm not cute or built to suit a fashion model's size

The speaker in this poem tell how special she is, every people don't believe what was the secret that make her so phenomenal? She tell if she is pretty women wonder where her secret lies, she is not cute or built a suit fashion models size. The word of pretty women and fashion models size include of the visual imagery. In second stanza:

Line 22 - It's the fire in my eyes,

Line 23 - And the flash of my teeth,

Line 24 - The swing in my waist,

In the third stanza:

Line 38 It's in the arch of my back,

And the last stanza: 
Line 54 - The bend of my hair,

The speaker tells if this poem boasts that a woman is more than the sum of her parts, much more. She is enigmatic, magnetic and is also capable of defining her own beauty. The word of fire in my eyes, flash of my teeth, swing in my waist, arch of my back, bend of my hair is include of the visual imagery. It describes how phenomenal she is.

Based on Pradopo, (1990: 81) visual imagery appeals to the sense of sight by describing something the speaker of the poem sees. Poets will use other figurative language, such as metaphor, simile or personification to describe these images. So the words of Pretty women, cute, fashion model's size, fire in my eyes, flash of my teeth, swing in my waist, arch of my back And bend of my hair is include of visual imagery because the speaker of the poem describes what objects she sees or makes them seem like something else.

Fourth Poem Is When I think about myself. In this poem, Angelou presents the perspective of an aging maid to make a statement about blacks surviving in a world dominated by whites.

This poem has three stanzas but there is no visual imagery in this poem And the last poem is Alone. Alone is a poem that deals with togetherness by placing emphasis on being alone, quite an irony. It is a lyrical "thinking out loud", a reflection on what it is to be a human and 'out here' in the big wide world.

In first stanza:

Line 4 - Where water is not thirsty

Line 5 - 5 And bread loaf is not stone

In third stanza:

Line 15 - With money they can't use

The speaker of this poem tells if we cannot life alone in the world, nobody can make it in the world alone. The speaker introduces the idea that wealth alone cannot bring spiritual wellbeing and happiness. Having too much money only isolates people further.

Based on Pradopo, (1990: 81) visual imagery appeals to the sense of sight by describing something the speaker of the poem sees. Poets will use other

\section{British, Jurnal Bahasa dan Sastra Inggris}


figurative language, such as metaphor, simile or personification to describe these images. So the words of water, bread loaf, stone and money is include of visual imagery because the speaker of the poem describes what objects she sees or makes them seem like something else.

\section{Auditory Imagery}

Poets can also describe sounds that are heard, which is called auditory imagery. Poets might also use sound devices like onomatopoeia, or words that imitate sounds, as a means of describing sounds.

First poem is I know why the caged bird sings

Line 9 - The caged bird sings with a fearful trill

Line 11 - and his tune is heard on the distant hill

In fifth stanza:

Line 18 - his shadow shouts on a nightmare scream

The speaker tells how tortured the caged bird. She just can sings with a fearful trill and his tune heard until on the distant hill and his shadow shouts on nightmare scream. The word of sings, fearful trill, tune, shout, and scream is appeal to the sense of auditory. Based on Pradopo (1990:81) Poets can also describe sounds that are heard, which is called auditory imagery. Poets might also use sound devices like onomatopoeia, or words that imitate sounds, as a means of describing sounds. So the words of bird sings, a fearful trill, his tune, shadow shouts and scream is include of auditory imagery that describing sounds.

Second poem is Still I Rise

In fifth stanza:

Line 19 - 'Cause I laugh like I've got gold mines

The poem in this speaker tells if she can laugh very loose like she got gold mines. The word of laugh included of auditory imagery.

Based on Pradopo (1990:81) Poets can also describe sounds that are heard, which is called auditory imagery. Poets might also use sound devices like onomatopoeia, or words that imitate sounds, as a means of describing sounds. So the word of 'Cause I laugh like I've got gold mines include of auditory imagery that describing the sounds. 
Third poem is Phenomenal woman

In fourth stanza:

Line 48 - I don't shout or jump about

Line 49 - Or have to talk real loud.

The speaker in this poem tells if she didn't have to shout or jump about or have talk real loud to take their attention.

Based on Pradopo (1990:81) Poets can also describe sounds that are heard, which is called auditory imagery. Poets might also use sound devices like onomatopoeia, or words that imitate sounds, as a means of describing sounds. So the words of shout and talk real loud is include of auditory imagery that describing the sounds.

Fourth poem is When I think about myself

In last stanza:

Line 16 - I laughed so hard I nearly died,

The speaker in this poem tell she laughed so hard to mask how hard the reality of this world to her. Based on Pradopo (1990:81) Poets can also describe sounds that are heard, which is called auditory imagery. Poets might also use sound devices like onomatopoeia, or words that imitate sounds, as a means of describing sounds. So the word of I laughed so hard is include of auditory imagery that describing the sounds.

Last poem is Alone

In third stanza:

Line 17 - Their children sing the blues

In fifth stanza:

Line 31 - And I can hear the moan,

The speaker in this poem tell if there are some millionaires with money they can't use their wives run round like banshees their children sing the blues they've got expensive doctors to cure their hearts of stone, But nobody can make it out here alone. In short, you can have all the money in the world, but you may still lose your soul.

Based on Pradopo (1990:81) Poets can also describe sounds that are heard, which is called auditory imagery. Poets might also use sound devices like onomatopoeia, 
or words that imitate sounds, as a means of describing sounds. So the words of sing the blues and the moan is include of auditory imagery that describing the sounds.

\section{Tactile Imagery}

Based on Pradopo (1990:81) Describing the way something feels is called tactile imagery. This type of imagery might define characteristics like hardness, softness, wetness, heat or cold, according to Friends of Robert Frost.

In forth stanza:

In line 14 - and the trade winds soft through the sighing trees

In this line, the speaker said if the free bird can fly like she wants and trade winds soft trough the sighing trees. The word of soft in this line is included in tactile imagery.

\section{Gustatory Imagery}

Imagery describing taste sensations is also referred to as gustatory imagery. In Gustatory Imagery, the researcher found just one poem that used this sense in Still I Rise.

In first stanza:

Line 2 - With your bitter, twisted lies,

The speaker in this poem tell if how their abused her with their bitter and twisted lies to make her down. Based on Pradopo (1990:82) Imagery describing taste sensations is also referred to as gustatory imagery. Poets appeal to this sense by explaining what something tastes like, which can be particularly effective if the description is something the reader is familiar with. So the word of bitter is included in gustatory imagery.

\section{Kinesthetic Imagery}

Kinesthetic imagery depicts something that is actually not moving or motion picture in general. Kinesthetic imagery can make something feel alive and feel dynamic. This is the last kinds of imagery that used in poem.

First poem is I know why the caged bird sings.

In first stanza:

In line 1 - A free bird leaps on the back

\section{British, Jurnal Bahasa dan Sastra Inggris}


Like in visual imagery discussion above In this line the speaker tells about a free bird leaps on the back wind that means she can do anything she wants. But the word of leaps in this line that included in kinesthetic imagery.

In second stanza:

In line 8 - so he opens his throat to sing

In this line, the speaker tells if there is nothing that the caged bird does in her cage like the free bird do. So she just can opens his throat to sing. The word of opens that included in kinesthetic imagery.

In last stanza:

In line 22 - with a fearful trill of things unknown

In this line tell about how poor the caged bird, she just always sings with a fearful trill of things that she didn't know in her cage. The word of fearful trill include of kinesthetic imagery.

Based on Pradopo (1990:81) Kinesthetic imagery describes the sense of movement, and it could refer to the movement of the speaker or objects around the speaker of the poem. The words of bird leaps, opens and fearful trill is include in kinesthetic imagery because this words refer to the movement.

Second poem is Still I Rise

In first stanza:

Line 1 - You may write me down in history

Line 4 - But still, like dust, I'll rise.

The speaker in this poem tell if how their abused her she is fine although they write down her in history. With their bitter and twisted lies to make her down. She still will rise. The word of write and I'll rise is include of gustatory imagery.

In Second stanza

Line 7 - 'Cause I walk like I've got oil wells

The speaker tell if she will always hold on because she walk like, she got oil wells. The word of walk include of kinesthetic imagery.

In fourth stanza:

Line 15 - Shoulders falling down like teardrops 
The speaker in this poem tell although their doing to her, she will never give up like shoulder falling down. The word of falling down included of kinesthetic imagery.

In fifth stanza:

Line 20 - Diggin' in my own back yard

In sixth stanza:

Line 21 - You may shoot me with your words,

Line 22 - You may cut me with your eyes,

Line 23 - You may kill me with your hatefulness,

The speaker in this poem tell although their shoot, or kill me she will still rise.

The word of digging, shoot, cut, and kill included of kinesthetic imagery.

In seventh stanza:

Line 27 - That I dance like I've got diamonds

In eight stanza:

Line 33 - I'm a black ocean, leaping and wide,

In nine stanza:

Line 35 - Leaving behind nights of terror and fear

Line 39 - Bringing the gifts that my ancestors gave,

From seventh until nine stanza describing if whatever they do to her, she will never invincible she still will rise. The word of dance, leaping, leaving, and bringing included of kinesthetic imagery.

Based on Pradopo (1990:81) Kinesthetic imagery describes the sense of movement, and it could refer to the movement of the speaker or objects around the speaker of the poem. The words of write, I'll rise, walk, falling down, Diggin', shoot, cut me, kill me, dance, leaping, Leaving, and Bringing is include in kinesthetic imagery because this words refer to the movement.

Third poem is Phenomenal Woman

In second stanza:

Line 2 - I walk into a room

The speaker of this poem tell if she walk into a room all of the attention will be on her. 
Line 18 - Fall down on their knees.

The speaker in this poem tells if everything on her will make all man fall down on their knees. The word of fall down included of kinesthetic imagery.

Based on Pradopo (1990:81) Kinesthetic imagery describes the sense of movement, and it could refer to the movement of the speaker or objects around the speaker of the poem. The words of walk and Fall down is include in kinesthetic imagery because this words refer to the movement.

Fourth poem is When I Think About My Self

In first stanza:

Line 4 - A dance that's walked

The speaker in this poem tell her dark past, One of her experience is dance that's walked. Albeit the laughter chokes, aches and makes her cry. The word of dance and walked include of kinesthetic imagery.

Based on Pradopo (1990:81) Kinesthetic imagery describes the sense of movement, and it could refer to the movement of the speaker or objects around the speaker of the poem. The words of a dance that's walked is include in kinesthetic imagery because this words refer to the movement.

Last poem is Alone

In third stanza:

Line 16 - Their wives run round like banshees

The speaker introduces the idea that wealth alone cannot bring spiritual wellbeing and happiness. Having too much money only isolates people further.

Based on Pradopo (1990: 81), kinesthetic imagery describes the sense of movement, and it could refer to the movement of the speaker or objects around the speaker of the poem. The word of run is included in kinesthetic imagery because this word refer to the movement.

\section{CONCLUSIONS AND SUGGESTIONS}

This section deals with the research conclusion and some suggestion based on the result of the research findings and discussions that explained above. 
Based on the finding and discussion on the previous chapter, the researcher found five kinds of imagery that used in Maya Angelou poem selected. Those are visual imagery there are 26 words, auditory imagery there are 11 words, tactile imagery just 1 word, gustatory imagery just 1 word too and last kinesthetic imagery there are 20 words. After doing the four steps of analyzing the data, it was identification, classification, interpreting and describing the data, now the last step is conclusion. Based on the data analyzed the researcher conclude if the most of the kinds of imagery that the researcher found Maya Angelou selected poem " $I$ Know Why The Caged Bird Sing, Still I Rise, Phenomenal Woman, When I Think About My Self and the last is Alone" is Auditory Imagery.

The researcher suggested some suggestion for the reader and the next researcher that will be interested to analyze some poem or poetry. First, for the readers the researcher hope based on this analyze the readers can understand how to find out the imagery in one or two poems and can help you understand the meaning of the poem. And for the next researcher, the researcher hope this research can help to more complete yours research and this research can be yours previous study.

\section{REFERENCES}

Aminuddin. 2004. Pengantar Apresiasi Karya Sastra. Bandung: Sinar Baru Algensindo.

Andini, Dewi. (2014). Unsur - Unsur Instrinsik Puisi. Retrieved on December 13, 2014, 6:54:18 PM. http://andinijs.blogspot.com/2014/05/unsur-unsurintrinsik-puisi.html

Bodgan, R dan Steven J.T. (1993). Kualitative Dasar-Dasar Penelitian. Diterjemahkan oleh A Khozin Afandi. Surabaya: Usaha Nasional

Burhan Nurgiyantoro. 1995. Teori Pengkajian Fiksi. Yogyakarta: Gadjah Mada University Press.

Denzin, N.K. and Lincoln, Y.S. (1984), Handbook of Qualitative Research, Newbury Park: Sage Publications 
Departemen Pendidikan dan Kebudayaan. 1997. Kamus Besar Bahasa Indonesia. Jakarta: Balai Pustaka.

Eka S. (2012). Analisis Unsur Intrinsik dengan Pendekatan Struktural. Retrieved on December $\quad 1^{\text {st }} \quad 2014, \quad 11: 17: 22 \quad$ AM. https://bestlina.wordpress.com/2012/08/04/analisis-unsur-intrinsikdengan-pendekatan-struktural/

Flanagan, Mark. (2014). What is poetry? Retrieved on November 03, 2014, 12:53:44 AM. http://contemporarylit.about.com/od/poetry/a/poetry.htm Nordquist, Richard. (2014). Imagery (Language). Retrieved on November 03, 2014, 12:09:46 AM.http://grammar.about.com/od/il/g/imageryterm.htm

Pradopo, Rachmad Djoko. 2007. Pengkajian Puisi. Yogyakarta: Gadjah Mada University. Press.

2012. Pengkajian Puisi. Yogyakarta: Gadjah Mada University Press.

Siswanto, Wahyudi. 2008. Pengantar Teori Sastra. Bandung: Grasindo.

Sugiono. 2012. Memahami Penelitian Kualitatif. Bandung: Muhammadiyah University Press.

Sugiyono. 2013. Metode Penelitian Kuantitatif Kualitatif dan $R \& D$. Bandung: Alfabeta

Tarigan, Henry Guntur. 1984. Prinsip-Prinsip Dasar Sastra. Bandung: Angkasa.

Waluyo, J. Herman. 1991. Teori dan Apresiasi Puisi. Bandung: Angkasa. 